\title{
ARTEMISIA SANTONICUM SUBSP. PATENS IN SLOVAKIA: THE SAD STORY OF OBLIGATE HALOPHYTE ON THE NORTHERN EDGE OF ITS DISTRIBUTION RANGE
}

\author{
Daniel DÍTĚ ${ }^{1}$, Pavol ELIÁŠ jun. ${ }^{2}$ \& Zuzana MELEČKOVÁ ${ }^{1}$
}

\begin{abstract}
Historical and current occurrence of obligate halophyte Artemisia santonicum subsp. patens was studied in Slovakia during 2001-2012. The species has been occurred in the Podunajská nížina Lowland and the Východoslovenská nížina Lowland; 35 localities were found in total. The data from the Záhorská nížina Lowland is erroneous. Recently the number of localities decreased markedly and the species was confirmed only in 17 sites. Most of them (16) is situated in the Podunajská nížina Lowland and a single one has been confirmed in the Východoslovenská nížina Lowland. Based on our data, Artemisia santonicum subsp. patens belongs to the endangered (EN A2ac+4c) plants of the Slovak flora according to IUCN categories and criteria, because $50 \%$ of locations were destroyed and survival prognosis is unfavorable for the most recent populations.

Key words: Artemisia santonicum subsp. patens, Slovakia, occurrence, halophytes, IUCN criteria.

\section{Izvleček}

V članku smo obravnavali historično in trenutno razširjenost obligatne halofitske vrste Artemisia santonicum subsp. patens na Slovaškem med leti 2001 in 2012. Vrsta se pojavlja v nižinah Podunajská nížina in Východoslovenská nížina; skupno smo našli 35 rastišč. Podatki o pojavljanju v nižini Záhorská nížina so napačni. Število rastišč se je v zadnjem času občutno zmanjšalo in pojavljanje vrste smo potrdili samo na 17 lokalitetah. Večina (16) je iz Podunajská nížina in samo ena iz Východoslovenská nížina. Na podlagi naših podatkov takson $A r-$ temisia santonicum subsp. patens uvrščamo med ogrožene (EN A2ac+4c) vrste slovaške flore na podlagi IUCN kategorij in kriterijev, saj je bilo uničenih $50 \%$ rastišč in tudi napovedi za preživetje trenutnih populacij so neugodne.
\end{abstract}

Ključne besede: Artemisia santonicum subsp. patens, pojavljanje, halofiti, IUCN kriterij.

\section{INTRODUCTION}

The genus Artemisia is one of the largest genera in Asteraceae family. It is comprised of about 200-500 taxa widely distributed in the Northern Hemisphere but poorly represented in the Southern Hemisphere (Bremer \& Humphries 1993, Vallés \& McArthur 2001). Most of taxa are occurred especially in Eurasia including also the species Artemisia santonicum L. [syn. A. monogyna Waldst. et Kit., A. maritima subsp. monogyna
(Waldst. \& Kit.) Hegi]. Artemisia santonicum, very variable taxon from $A$. maritima group, is usually divided to two subspecies: subsp. santonicum and subsp. patens (Neilr.) K. M. Perss [syn. A. maritima var. patens Neilr., A. salina subsp. patens (Neilr.) Sagorski, A. santonicum subsp. pannonicum Guterm., nom illeg.]. The nominate subspecies is distributed from eastern Austria to western Romania and Hungary (Persson 1974, Tutin \& Persson 1976, Penksza \& Király 2009). The second one occupy wide area in Eurasia from east-

\footnotetext{
${ }^{1}$ Institute of Botany, Slovak Academy of Sciences, Dúbravská cesta 9, SK-845 23, Bratislava, Slovakia, daniel.dite(a) savba.sk, zuzana.meleckova@savba.sk

${ }^{2}$ Department of Botany, Slovak University of Agriculture, Tr. A. Hlinku 2, SK-949 76 Nitra, Slovakia, pavol.elias.jun@ gmail.com
} 
ern Austria, Slovakia, Hungary, Romania, Serbia (Voyvodina), Croatia, southern Ukraine, central and southern Russia, western Kazakhstan, northeast Greece, and Turkey; it is missing in NW part of the Pannonian Basin in the Czech Republic (Persson 1974, Tutin \& Persson 1976, Kurşat et al. 2011). In Slovakia, only subsp. patens was confirmed (Dostál \& Červenka 1992, Marhold \& Hindák 1998, Grulich \& Feráková 1999).

Artemisia santonicum subsp. patens occurrs only in the southern part of Slovakia in the lowland regions. Here, the species has reached the northern limit of its distribution range (Grulich \& Feráková 1999). A. santonicum subsp. patens belongs to the group of obligate halophytes. The number of localities has significantly reduced on the northern edge of its range (Sádovský et al. 2004, Eliáš jun. et al. 2008, Dítě et al. 2012). For this reason the species was classified as "endangered" (EN) in Red Lists of Slovakia and Austria (Niklfeld \& Schratt-Ehrendorfer 1999, Feráková et al. 2001).

Artemisia santonicum is a typical herb of the Pannonian salt steppes (Krippelová 1965, Mucina 1993, Borhidi 2003), and it is a member of various plant communities of salt-affected soils. It has the optimum occurrence in communities of Festuco-Puccinellietea, especially in the association Artemisio santonici-Festucetum pseudovinae. The species has reached the highest coverage in this type of vegetation also in the salt habitats of Slovakia (Vicherek 1973, Dítě et al. 2010a), however, Artemisia santonicum subsp. patens was found also in other communities: Camphorosmetum annuae (Krippelová 1965, Dítě et al. 2008), Puccinellietum limosae (Vicherek 1973, Zlinská 2003, Dítě et al. 2009), and Hordeetum hystricis (Dítě et al. 2011a). Vicherek (1973) found it also in the stands of association Achilleo setaceae-Festucetum pseudovinae.

Borhidi (2003) pointed out association Limonio-Artemisietum santonici (Soó 1927) Topa 1939 from Hungary belonging to alliance Puccinellion limosae. This association was referred mistakenly to Slovakia (Vicherek 1973); Mucina (1993) mentioned it also from the surrounding of the lake Neusiedl in Austria. According to Borhidi (2003) this association occurs only in the southern part of the Hortobágy, which has welldeveloped typical stands and also degraded, floristically impoverished secondary stands. He also indicates the species in the association PeucedanoAsteretum sedifolii Soó 1947 corr. Borhidi 1996 (alliance Peucedano officinalis-Asterion sedifolii Borhidi
1996). This community was not reported from the area of Slovakia. Borhidi \& Sánta (1999) mentioned the species also from associations Agrostio -Caricetum distantis Rapaics ex Soó 1938 and Pholiuro-Plantaginetum tenuiflorae Wendelberger 1943.

This work is aimed to analyse historical and recent occurrence of Artemisia santonicum subsp. patens in Slovakia, to characterise all current populations and to evaluate the Red List status of the species using IUCN categories and criteria.

\section{MATERIAL AND METHODS}

The study was carried out during the years 2001 - 2012 in the Podunajská nížina Lowland and Východoslovenská nížina Lowland. The data concerning the distribution of the species was obtained from herbaria BP, BRA, BRNU, BRNM, CL, LTM, MMI, MZ, NI, KO, OLM, PMK, PR, PRC, SAV, SLO and ZV. Herbarium abbreviations are according to Holmgren et al. (1990) and Vozárová \& Sutorý (2001). Those results are presented on the point map designed by program ArcGis, version 9.2. Coordinates of recent localities were obtained during field research using GPS equipment Garmin CS 60; the numbers of grid squares follow one that was described by Niklfeld (1971). A list of localities was compiled according to the directives of the Flóra Slovenska VI/1 (cf. Goliašová \& Šípošová 2008).

The abbreviations of works published before 1956 are cited according to Futák \& Domin (1960) and the nomenclature of flowering plants follows Marhold \& Hindák (1998). Phytogeographical divisions are used by Futák (1980).

The state of the populations of Artemisia santonicum at the individual locations are determined on a scale from 1 to 5 , where 1 represents the most favourable state, 5 the worst:

1) population stabilized under the current conditions,

2) population with slightly decreasing frequency, but conditions of locality are relatively stable,

3) population with decreasing frequency and conditions of locality are under pressure of negative factors (secondary succesion, human activities - tillage, recultivations, construction of buildings etc.),

4) residual population (markedly reduced), threatened with extinction,

5) population extinct, not confirmed during our research. 
Status of the populations was estimated based on repeated phytosociological relevés, monitoring on permanent plots, in rare cases, subjective, based on the estimation of abundance and population sizes.

\section{RESULTS}

As showed our research, 35 locations of Artemisia santonicum were documented overlall in Slovakia. Recently, we have confirmed the occurrence of $A$. santonicum on 17 sites (Fig. 1). Most of them (16) are situated in the Podunajská nížina Lowland in the broad surroundings of the settlements of Nitra (Močenok), Nové Zámky (Jatov, Tvrdošovce, Palárikovo, Šrany) and Štúrovo (Kamenín, Kamenný Most). The single population is still surviving in the Východoslovenská nížina Lowland near the village of Kopčany. Data about occurrence of A. santonicum in the Záhorská nížina is incorrect.

Comparing the historical and recent data, $50 \%$ of locations were destroyed in the past and survival prognosis is unfavorable for the most of the recent populations. Therefore, the IUCN status of $A$. santonicum was confirmed in category "endangered" (EN A2ac+4c) according Feráková et al. (2001)
A more detailed information about the current populations of Artemisia santonicum subsp. patens in Slovakia is listed below:

\section{Š́r National Nature Reserve, part Panónsky háj}

From originally large population of $A$. santonicum there have have been preserved only some degraded remnants of the halophytic vegetation in this locality. The species occupies shallow depressions, former salt pans according to the shape of the terrain, creating degraded stands of the association Artemisio santonici-Festucetum pseudovinae. In 2011, only two small places occupying an area not more than $10 \mathrm{~m}^{2}$ were found.

State of population: 4 .

\section{Komjatice, Ružový dvor farmstead}

The halophytic vegetation on the site was ploughed in the end of the seventies of the last century and than left fallow. On the most salinized places, Artemisia santonicum has created dense stands with abundance more than $80 \%$. This secondary vegetation is similar to ass. Artemisio santonici-Festucetum pseudovinae (Dítě et al. 2010a), however, the population of the species and the stands of other accompanying halophytes (Festuca pseudovina, Plantago maritima, Puccinellia

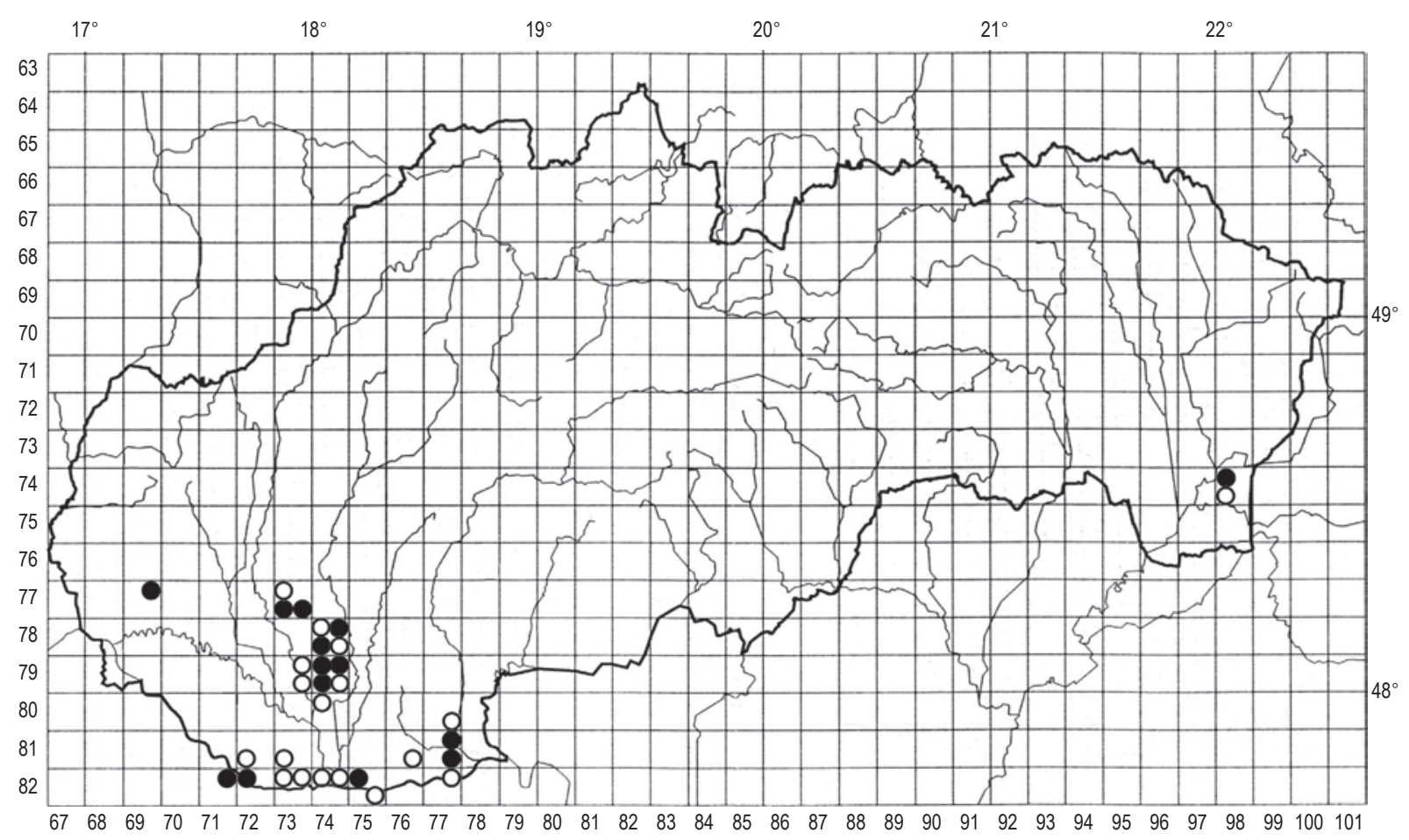

Figure 1: Historical ( $($ ) and recent $(\bullet)$ distribution of Artemisia santonicum subsp. patens in Slovakia.

Slika 1: Zgodovinska $(\circ)$ in današnja $(\bullet)$ razširjenost vrste Artemisia santonicum subsp. patens na Slovaškem. 
distans agg.) gradually decreased due to the strong pressure of mesophilic meadow (Arrhenatherum elatius) and ruderal species (Elytrigia repens, Dipsacus fullonum).

State of population: 3 .

\section{Močenok, Siky farmstead}

The last locality covered by relatively well-preserved halophytic vegetation in Slovakia. These stands with high amount of salts in the soil are intensively grazed by sheep and are dominated by Puccinellia distans agg., but there are also some fragments of ass. Artemisio santonici-Festucetum pseudovinae covering an area of about 0.25 ha. Due to the grazing of sheep, those fragments are not existentially threatened by the secondary succession.

State of population: 1.

\section{Močenok, site SW from the Siky farmstead}

The second site including some populations of Artemisia santonicum is situated ca $1.5 \mathrm{~km} \mathrm{SW}$ from the above mentioned one. This saline habitat was abandoned and partly afforested with Fraxinus pennsylvanica ca 40 years ago, but the stands of $A$. santonicum are still in good condition. These are one of the richest populations of the species in Slovakia.

State of population: 2.

\section{Jatov, saline meadows south from the village}

In 2008, we confirmed a relatively large saline habitat of ca 10 ha, where moderately saline meadows predominated. This site belongs to the large complex of saline vegetation situated between settlements of Močenok and Palárikovo, but mostly destroyed and fragmented in the second half of 20th century. Halophytic plant communities with dominance of association Artemisio santonici-Festucetum pseudovinae were preserved only in the south-east edge covering area ca 1.5 ha. Unfortunately, this locality was completely destroyed by tillage in spring 2012 .

State of population: $\mathbf{5}$.

\section{Tvrdošovce, Panské lúky site}

The rest of both halophytic and meadow vegetation mosaic is situated north-west from the village along to railway N. Zámky - Šal'a. As the majority of the Slovak sites, degradation processes are also in progress, but a relatively abundant population of $A$. santonicum was still maintaining here creating more or less typical stands of ass. Artemisio santonici-Festucetum pseudovinae. De- spite the fact that the site was included in Natura 2000 localities; more than $70 \%$ was ploughed up in spring 2012. Fortunately, the major part of the A. santonicum population was survived.

State of population: 3 .

\section{Tvrdošovce, surrounding of the Ráczovo jazier-} ko pool

The site is located on the northern edge of the village near the small saline pool named Ráczovo jazierko. It was in relatively good condition not so far in the past, there was found a mosaic of numerous plant communities of salt steppes and periodically flooded salt habitats along the banks of the pool (Svobodová \& Řehořek1988, Valachovič 1995). The most valuable associations were ass. Crypsidetum aculeate (Eliáš et al. 2008) and Atriplici prostratae-Chenopodietum crassifolii (Eliáš et al. 2009). The mosaic of communities hosts several patches with a well-developed stands of Artemisio santonici-Festucetum pseudovinae with a large population of $A$. santonicum. Today, due to the gradual degradation of the locality (e.g. it was used as waste deposit, termination of constant grazing) significant vegetation changes have turned until vanishing of several communities (e.g. Crypsidetum aculeatae). This process has also a negative impact to the abundance of $A$. santonicum, the population size has been decreasing.

State of population: 4 .

\section{Palárikovo, NE from the train station}

The site represents small remnant of formerly largely expanding saline habitat. In the beginning of 21th century we confirmed only a small population covering an area of ca $40 \mathrm{~m}^{2}$. Later, in very wet year 2010, the locality was flooded and dried up in the next year. It had fatal consequences for the population of the species; only a few, not more than 10 individuals of $A$. santonicum were found in 2012 on a mound of the saline soil excavated for creating a small pond for the game. This heap was not flooded and served as refuge for A. santonicum.

State of population: 4 .

\section{Palárikovo, Malé Čiky farmstead (Figure 2)}

The site represents a relatively large remnant of about 90 ha saline habitats surrounded by intensively used fields. Despite the damage of the site in the past (drainage, attempts to ploughing and afforestation of several parts), fragments of halophytic vegetation are still preserved in some 


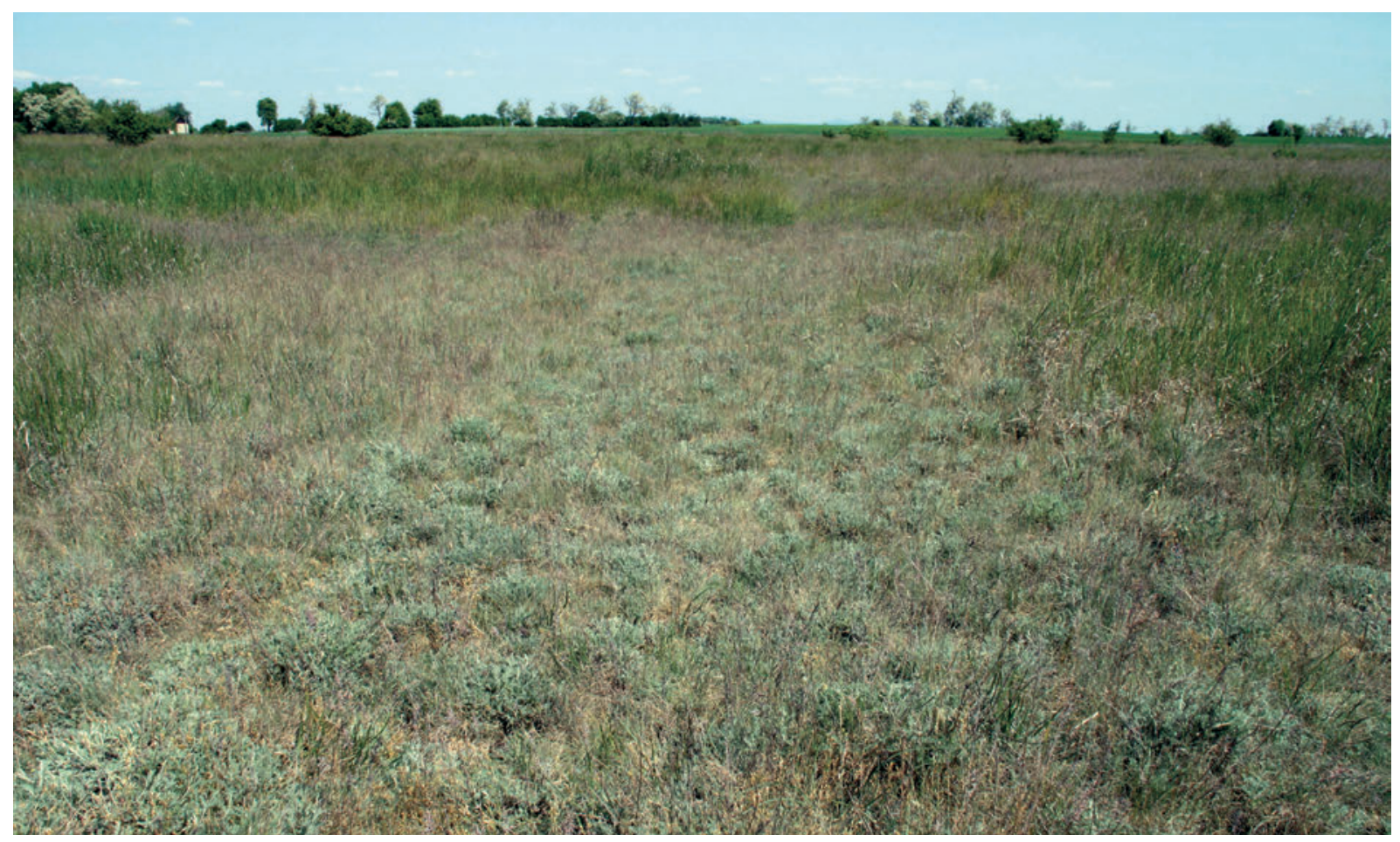

Figure 2: Relatively large stand of Artemisia santonicum subsp. patens surrounded by vegetetion of Molinio-Arrhenatheretea in Malé Čiky site.

Slika 2: Relativno velik sestoj vrste Artemisia santonicum subsp. patens, ki ga obkroža vegetacija razreda Molinio-Arrhenatheretea na lokaliteti Malé Čiky.

places within the site, including also well developed stands of ass. Artemisio santonici-Festucetum pseudovinae (Dítě et al. 2010a).

State of population: 3 .

\section{Šurany, Akomáň farmstead}

Around the year 2000, it was one of the best preserved remnants of saline habitats in Slovakia, with the presence of almost all typical obligate halophytes (Eliáš et al. 2008, 2010, 2011b; Dítě et al. 2012) and the last known location of association Pholiuro pannonici-Plantaginetum tenuiflorae (Dítě et al. 2010b). Artemisia santonicum recently grows there in the relatively well developed stands of ass. Artemisio santonici-Festucetum pseudovinae. Due to the significant reduction of sheep grazing there in recent years, there starts a rapid degradation of the vegetation including stands with dominance of Artemisia santonicum e.g. number of species is increasing including mezophilous (Arrhenatherum elatius, Bromus hordeaceus) and ruderal taxa (Cirsium arvense, Dipsacus fullonum).

State of population: $\mathbf{4}$.

\section{Vel'ké Kosihy, Mostové Nature Reserve}

Despite the territorial protection of this site (from 2000), some parts of it have been ploughed up in 2003. The conditions of the saline vegetation have gradually worsened due to the lack of the traditional farming (pasture) and the desalination of the soil, however, the site is mown annually. Salt pans which were even 5 years ago covered by Camphorosma annua (Dítě et al. 2008), now practically disappeared (Eliáš jun., Dítě \& Melečková 2011 ined.). The area of Artemisio santonici-Festucetum pseudovinae was also dramatically reduced. Recently, there is only a residual presence on several $\mathrm{m}^{2}$.

State of population: 4 .

\section{Okánikovo, rest of saline habitat near the cemetery}

Markedly degraded (ruderalised) and afforested site on strongly salt-affected soil occupying an area about $1.5 \mathrm{ha}$. The small $A$. santonicum population including ca 20 individuals was found here in 2010; in 2011 some plants were buried by construction waste (bricks and fragments 
of plaster). Floristically important site, some very rare species as Elatine hungarica, Lythrum tribracteatum and Schoenoplectus supinus were found here (Király \& Eliáš jun. 2011, Eliáš jun. et al. 2011b).

State of population: 4 .

\section{Zlatná na Ostrove, Pavel farmstead}

Two fragments of halophytic vegetation have been preserved near the chicken farm on place of the former Pavel farmstead separated by the railway line. The larger population situated south from the railroad; it was relatively well-preserved saline habitat with rich populations of several halophytes until around 2005. A. santonicum was recorded mainly in the relatively preserved residues of ass. Artemisio santonici-Festucetum pseudovinae. Since 2005, the negative vegetation changes (secondary succession) have begun to cause large reduction of population size of $A$. santonicum. In 2011, we recorded only a few individuals.

State of population: 4 .

The second, smaller site is situated north from the railway line. At the turn of the millennium, it was the one of the best preserved remnants of salt steppes in Slovakia. However, in 2003, vegetation cover was devastated by ploughing in order to grow barley and then it has been abandoned. Most salinized places were occupied by some halophytes: Tripolium pannonicum, Plantago maritima, Puccinellia distans agg. Atriplex littoralis occurred in the first years after the tillage. Sporadically it was recorded Artemisia santonicum in the permanent plots, too with no more than $1 \%$ cover (Dítě, Eliáš jun. \& Melečková ined.). Since 2009, the species was not found here. State population: $\mathbf{5}$.

\section{Iža, Bokrošské slanisko Nature Reserve}

The vegetation cover of this site was already damaged before the declaration as a protected area (in 1988) by land reclamation practices (tillage, attempt to afforestation) (Klokner 1985, Zlinská 2005). The last remnants outside of the nature reserve were destroyed after construction of the municipal solid waste landfill at the end of 1990-ies. Populations of obligate halophytes (Camphorosma annua, Artemisia santonicum, Plantago maritima) survived only in small fragments in the western part of the reserve; regarding the current state of the locality, their existence is questionable in the future.

State of population: 4 .
Kamenín, Kamenínske slanisko National Nature Reserve (Figure 3)

The site is a part of the once large saline habitat stretching north from the Štúrovo town between villages of Nána and Bíňa (Krist 1940, Vicherek 1973). The reason for the protection (in 1953) was to preserve plant communities of saltaffected soils with the occurrence of almost all halophytes known from the territory of Slovakia. Some halophilous species, e.g. Limonium gmelinii, Ranunculus pedatus and Trifolium strictum, rare to the country are found only in this area. Currently, the state of halophytic vegetation is very unfavourable; degraded grasslands are developed on the most of the territory. Vegetation cover gradually tends to follow degradational stages of mesophilic meadows from class Molinio-Arrhenatherea (Melečková et al., 2010) as a result of desalinisation, absence of traditional use etc. Population of Artemisia santonicum is still relatively large, but it is under strong competitive pressure of some facultative halophytes (Galatella punctata), shrubs (Crataegus sp. div., Prunus spinosa) as well as meadow and ruderal species (Arrhenatherum elatius, Cirsium arvense, Dipsacus fullonum, Elytrigia repens).

State of population: 3 .

\section{Kamenný Most, Čistiny Nature Reserve}

The area was declared as a nature reserve in 2001, it is located south of Kamenínske slanisko National Nature Reserve, in its close proximity. Originally, though partially damaged Čistiny Nature Reserve was one of the most interesting halophytic habitats in Slovakia. In the mosaic of plant communities $A$. santonicum was recorded mainly in ass. Artemisio santonici-Festucetum pseudovinae, but it occurred in other vegetation types as well (Svobodová \& Řehořek 1988). Currently, vegetation cover represents degraded grasslands and follow stages of class Molinio-Arrhenatherea, several communities have disappeared completely (e.g. communities of funcion gerardii). Artemisia santonicum occupies only six residues of degraded stands of Artemisio santonici-Festucetum pseudovinae, an area up to $200 \mathrm{~m}^{2}$.

State of population: 4 .

\section{Kamenný Most, site near the field airport}

North of the Štúrovo town A. santonicum remained also in fragments of degraded halophytic vegetation near the field airport on the northern edge of the village of Kamenný Most. Sev- 


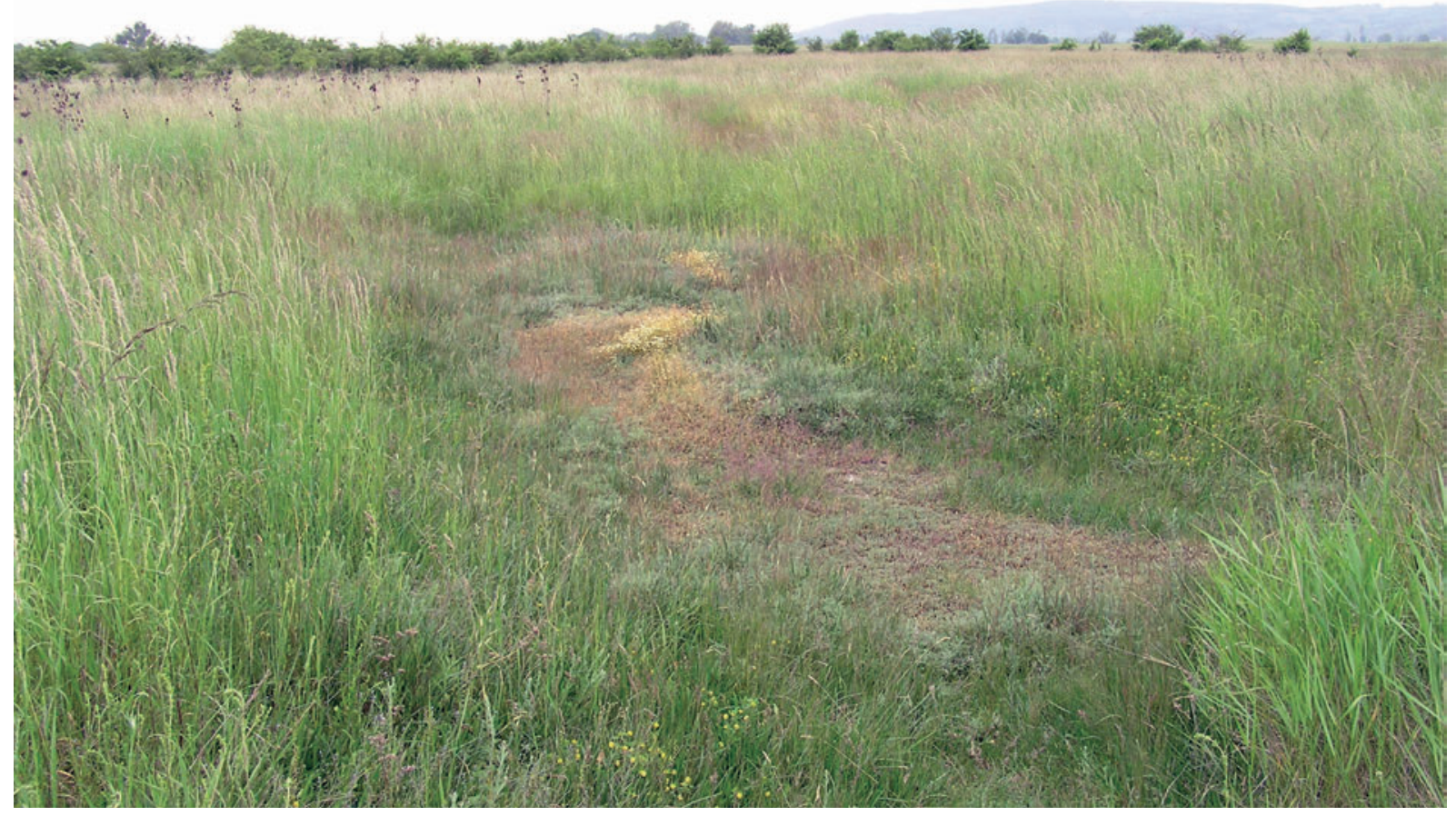

Figure 3: Absence of traditional management and desalinization of soil has caused reduction of population size of Artemisia santonicum subsp. patens in the Kamenínske slanisko Nature Reserve.

Slika 3: Odsotnost tradicionalnega gospodarjenja in razsoljevanje tal sta zmanjšala populacijo Artemisia santonicum subsp. patens v Naravnem rezervatu Kamenínske slanisko.

eral A. santonicum fragments accompanied with a large population of Limonium gmelinii cover now around 2 ha scatterely in the mesophilic grasslands dominated by Arrhenatherum elatius and Elytrigia repens. The site is under management, mown annually. Comparing to the other mown site described above (Mostové Nature Reserve in Vel'ké Kosihy), this locality is in more favourable stage.

State of population: 3 .

\section{Zemplínske Kopčany, Kopčianske slanisko Na- ture Reserve}

From the halophytic habitats originally ranged on several square kilometers in the Východoslovenská nížina Lowland (Vicherek 1964) in SE Slovakia, remained only small remnants in two nature reserves until today: Slavkovské slanisko and Kopčianske slanisko. Artemisia santonicum population survives now only in Kopčianske slanisko Nature Reserve covering an area no more than two $\mathrm{m}^{2}$ in the degraded stands of ass. Artemisio santonici-Festucetum pseudovinae. Since 2004 , its area has reduced by about $80 \%$.

State of population: 4.

\section{DISCUSSION}

Artemisia santonicum subsp. patens is considered to be as a phytogeographicaly important species and border element of the Slovak flora (Grulich \& Feráková 1999). It is a typical representative of the Pannonian salt steppes (Krippelová 1965, Borhidi 2003), however, on the northern edge of its distribution range it is disappearing rapidly.

The species has been documented for the first time in Slovakia by S. Feichtinger from Kamenný Most in 1853 (Feichtinger 1853 BP). However, works of Krist (1935, 1936, 1937, and 1940) have brought accurate data of its occurrence; he has published 10 sites in total. Other more or less detailed distribution data were published later by Vicherek (1973), Dostál \& Červenka (1992) and Grulich \& Feráková (1999). In addition to these principal works, some sites were also published by Jirásek (1937), Klika \& Vlach (1937), Šmarda (1952), Krippelová (1965), Klokner (1985), Svobodová \& Rehořek (1985, 1988, 1992), Zlínska (2003, 2005), Matušicová \& Černušáková (2005) etc. On the other hand, detailed occurrence of the species including revision of both literature and herbarium data was not published yet. 
In Slovakia, the species was reported from three separated regions situated in south of the country along border with Austria and Hungary (Grulich \& Feráková 1999). The smallest one was mentioned in the southwest, in the Záhorská nížina Lowland (Braun 1889, Degen et al. 1923). This statement in our opinion is a false data, since Braun mentions the species from the vegetation of sand dunes together with typical psammophytes as Alyssum montanum, Festuca vaginata and Helichrysum arenarium. Degen et al. (l. c.) only follows Braun`s data without critical approach. We believe that it is confusion with other Artemisia species (probably Artemisia campestris).

Most of locations of the species have been concentrated in the Podunajská nížina Lowland, mainly in its central and eastern parts. In the western part of this area, it occurs in the isolated locality of Šúr Nature Reserve, but most sites were situated among the towns of Nitra and Nové Zámky and then north from Štúrovo (Krist 1940, Vicherek 1973, Grulich \& Feráková 1999, Dítě et al. 2010a).

Other sites were concentrated in a small area of Východoslovenská nížina Lowland (Vicherek 1973, Dítě et al. 2010a). This isolated area of the species was found much later than the other locaties in SW Slovakia (Vicherek 1964). The occurrence of Artemisia santonicum has generally copied the occurrence of saline habitats here. According to the literature data, two locations were concentrated in the flat valley between the villages of Vel'ké Raškovce and Malčice in a relatively small area ocupying only 2-3 $\mathrm{km}^{2}$ (Vicherek 1964, 1973). As we found, there is only one existing site including only 10 individuals.

As our results showed, $A$. santonicum was relatively a common species of the halophytic flora of Slovakia (especially in the Podunajská nížina Lowland), 35 locations were found in total (Appendix, Fig. 1). The historical occurrence of the species illustrates very well the formerly distribution of saline habitats in Slovakia. The situation began to change in the 60 -ies and 70-ies of the 20th century. Marked reduction of both locations and population sizes was associated with large-scale destruction of salt-rich grasslands by land-reclamation; conversion to cropland, afforestation etc. (Sádovský et al. 2004, Fehér 2007). The last fragments that remained preserved until now are in poor condition due to the lack of traditional farming (grazing of cattle and sheep). Synergistic effect of desalination and the absence of grazing leads to significant changes in vegetation cover: we found expansion of ruderal species (Atriplex tatarica, Cirsium arvense, Dipsacus fullonum, Elytrigia repens,) and shrubs (Crataegus sp. div., Rosa sp. div.) as well as gradual retreat of halophilic communities towards successional stages of grasslands dominated by mesophilic species of class Molinio-Arrhenatheretea (Dítě et al. 2008, 2009, 2010a, b, 2011, Melečková et al. 2010, 2012). Similar situation is reported from the neighboring countries: in northwestern Hungary (Schmidt 2007) and South Moravia (Grulich 1987, Nováková 1997), where halophilic flora and vegetation has undergone through the same negative transition.

Artemisia santonicum populations can survive for a while the destruction of the vegetation cover caused by the above mentioned human activities. However, at certain succesional stage after the damage of the site, Artemisia santonicum tends to occupy patches with high soil salinity and by creating almost pure stands it indicates the former salt pans. Over time, populations of the species are reducing and $A$. santonicum becomes retreated from those damaged sites under the influence of deteriorating conditions (leaching salts from the soil, accumulation of plant biomass, penetration of ruderal species). On the other hand, A. santonicum has showed a very high ability to survive the destruction of the original halophyte vegetation. During the field investigations we have seen a more than one meter high specimens of Artemisia santonicum occupying a plantation of 40-year-old poplars at the Siky farmstead near the Močenok settlement (Dítě, Eliáš jun. \& Šuvada 2011 ined.). Its continual survival both in Podunajská and Východoslovenká nížina lowlands is directly dependent on the active management of the remaining sites. It is desirable to restore the grazing, which is technically very difficult (absence of herds of cattle and sheep, lack of stabling those animals etc.). It is questionable whether longterm mowing can maintain the populations in the sites.

\section{ACKNOWLEDGEMENTS}

We are indebted to Marek Sádovský (Úl'any nad Žitavou) and Róbert Šuvada (Rožňava) for help with field research. The paper was supported by the Slovak Grant Agency for Science VEGA (grant No. 2/0003/11). 


\section{REFERENCES}

Bogoly, J. 1994: Podkladové materiály pre potreby štátneho orgánu ochrany prírody z južnej časti Východoslovenskej nížiny na základe floristického a čiastočne aj zoologického mapovania. $124 \mathrm{pp}$, Manuscript.

Borhidi, A. 2003: Magyarország növénytársulásai. Akadémiai Kiadó, Budapest, 610 pp.

Borhidi, A. \& Sánta, A. (eds.) 1999: Vörös könyv Magyarország növénytársulásairól I-II. Természetbúvár Alapítvány Kiadó, Budapest, 766 pp.

Braun, H. 1889: Systematische Uebersicht and Verbreitung der Gattung Thymus L. in NiederOesterreich. Österreichische botanische Zeitschrift 39: 186-188.

Bremer, K. \& Humphries, C. J. 1993: Generic monograph of the Asteraceae-Anthemideae. Bulletin of the Natural History Museum of London (Botany) 23(2): 71-177.

Degen A., Gáyer J. \& Scheffer J. 1923: A detrekőcsütörtöki láp és a Morvamező keleti részének Flórája. Magyar Botanikai Lapok 22: 47-52.

Dítě, D., Eliáš, P. jun. \& Sádovský, M. 2008: Camphorosmetum annuae Rapaics ex Soó 1933 - vanishing plant community of saline habitats in Slovakia. Thaiszia - J. Bot., 18: 9-20.

Dítě, D., Eliášs, P. jun. \& Šuvada, R. 2009: The current distribution and status of community Puccinellietum limosae in Slovakia. Thaiszia - J. Bot., 19: 63-70.

Dítě, D., Eliáš, P. jun., Šuvada, R., Petrášová, A. \& Melečková, Z. 2010a: Current distribution and stage of community Artemisio santoniciFestucetum pseudovinae Soó in Máthé 1933 corr. Borhidi 1996 in Slovakia. Thaiszia - J. Bot., 20: 77-86.

Dítě, D., Eliáš, P. jun., Šuvada, R. \& Szombathová, N., 2010b: Ecology and coenotic characteristics of the Pholiuro pannonici-Plantaginetum tenuiflorae Wendelberger 1943 in the Pannonian Basin. Phyton (Horn) 49(2): 293-313.

Dítě, D., Eliáš, P. jun., Šuvada, R., Petrášová, A. \& Píś, V. 2011a: The present distribution and state of halophytic communities with Hordeum geniculatum in Slovakia. Thaiszia - J. Bot., 21: 11-20.

Dítě, D., Eliáš, P. jun. \& Melečková, Z., 2011b: Ohrozené druhy slanísk a ich spoločenstvá. Životné prostredie 45(5): 256-259.

Dítě, D., Eliáš, P. jun. \& Grulich, V. 2012: The revision of historical and current distribution of
Hordeum geniculatum All. in Slovakia. Hacquetia 11: 171-177.

Dostál, J. \& Červenka, M. 1992: Vel'ký klúč na určovanie vyšších vyšších rastlín II. Slovenské pedagogické nakladatel'stvo, Bratislava, $1561 \mathrm{pp}$.

Eliáš jun., P., Dítě, D., Grulich, V. \& Sádovský, M. 2008: Distribution and communities of Crypsis aculeata and Heleochloa schoenoides in Slovakia. Hacquetia 7(1): 5-20.

Eliáš, P. jun., Dítě, D. \& Šuvada, R., 2009: Contributions to recent occurrence and phytosociology of Chenopodium chenopodioides (L.) Aellen in Slovakia. Flora Pannonica 7: 43-49.

Eliáš, P. jun., Dítě, D., Grulich, V. \& Šuvada, R. 2010: Revision of historical and current distribution of Pholiurus pannonicus (Host) Trin. in Slovakia. Hacquetia 9(2): 177-183.

Eliáš, P. ml., Dítě, D., Melečková, Z. \& Zajac, M. 2011a: Recentné nálezy druhov Trifolium angulatum a Trifolium retusum na Podunajskej nížina. Bulletin Slovenskej Botanickej Spoločnosti, 33(1): 27-32.

Eliáš, P., Dítě, D., Melečková, Z. \& Király, G. 2011b: Poznámky k výskytu vybraných zriedkavých druhov pol'ných depresií na Podunajskej nížine (juhozápadné Slovensko). Zprávy České botanické společnosti 46(1): 1-12.

Fehér, A. 2007: Origin and development of the salt steppes and marshes in SW Slovakia. Flora Pannonica 5: 67-94.

Feráková, V., Maglocký, Š. \& Marhold, K. 2001: Červený zoznam paprad'orastov a semenných rastlín Slovenska (december 2001). Ochrana prírody, Banská Bystrica, 20 (Suppl.): 44-77.

Futák, J. 1980: Fytogeografické členenie SSR (1: 1000 000). In: Mazúr E. (ed.): Atlas Slovenskej socialistickej republiky. Bratislava, p. 81.

Futák, J. \& Domin, K. 1960: Bibliografia k flóre ČSR. Vyd. SAV, Bratislava, 884 pp.

Goliašová, K. \& Šípošová, H. (eds.) 2008: Flóra Slovenska VI/I. Veda, Bratislava, 420 pp.

Grulich, V. 1987: Slanomilné rostliny na jižní Moravě. ČSOP \& Regionální Muzeum Mikulov, Břeclav, 76 pp.

Grulich, V. \& Feráková, V. 1999: Artemisia santonicum subsp. patens (Neilr.) K. M. Perss. In: Čeřovský, J., Feráková, V., Holub, J., Maglocký, Š. \& Procházka, F. (eds.): Červená kniha ohrozených a vzácnych ruhov rastlín a živočíchov SR a ČR. Vol. 5. Vyššie rastliny. Príroda, Bratislava, $44 \mathrm{pp}$.

Holmgren, P. K., Holmgren, N. H. \& Barnett, L. 
C. (eds.) 1990: Index Herbariorum. Vol. 1: The herbaria of the World, Ed. 8. New York, 693 pp.

Jirásek, V. 1937: Příspěvek k poznání slaných stepí jihoslovenských. Věda přírodní 18: 20-22.

Király, G. \& Eliáš, P. jun. 2011: Elatinka mad'arská (Elatine hungarica) na Podunajskej nížine. Bulletin Slovenskej Botanickej Spoločnosti 33(1): 35-38.

Klika, J. \& Vlach, V. 1937: Pastviny a louky na szikách jižního Slovenska. Sborník Československé Akademie Zemědělské 12: 407-417.

Klokner, L. 1985: Flóra rekultivovaného slaniska Bokroš (Iža). Iuxta Danubium 5: 35-48.

Krippelová, T. 1965: Sol'né stepi na Žitnom ostrove. In: Janota, D. (ed.): Česko-slovenská ochrana prírody 2. Obzor, Bratislava, pp. 121-134.

Krist, V. 1935: Příspěvek $\mathrm{k}$ halofytní květene jižního Slovenska. Věda př́rodní 16: 897.

Krist, V. 1936: Př́íspěvek k poznání květeny československé I. Spisy vydavatelství Přirodovědovědecké Fakulty Masarykovy university Brno 222: 10.

Krist, V. 1937: Příspěvek k poznání květeny československé II. Spisy vydavatelství Přirodovědovědecké Fakulty Masarykovy university Brno 238: 56.

Krist, V. 1940: Halofytní vegetace jihozápadního Slovenska a severní části Malé Uherské nížiny. Práce moravské př́rodovědecké společnosti (Brno) 12(10): 1-100.

Kurşat, M., Türkoğlu, İ., Civelek, Ş. \& Tabur, S. 2011: A new subspecies record for the flora of Turkey: Artemisia santonicum L. subsp. patens (Neilr.) K. M. Perss. (Asteraceae). Turkish Journal of Botany 35: 89.

Marhold, K. \& Hindák, F. (eds.) 1998: Checklist of non-vascular and vascular plants of Slovakia. VEDA, Bratislava, 688 pp.

Matušicová, B. \& Černušáková, D. 2005: Chránené a ohrozené druhy cievnatých rastlín z okolia obcí Hájske, Horná Králová a Močenok na Podunajskej nížine. Bulletin Slovenskej botanickej spoločnosti 27: 71-76.

Melečková, Z., Dítě, D., Galvánek, D., Eliáš, P. jun., Šuvada, R., 2010: Is top soil removal a possible way for restoration of Pannonian saline habitats? In: Botta-Dukát, Z. \& SalamonAlbert, É. (eds.): 19-th EVS workshop Flora, vegetation, environment and land-use at large scale. Department of Plant Systematics and Geobotany, University of Pécs, Pécs, p. 65.
Melečková, Z., Dítě, D., Eliáš, P. jun. 2012: The actual chorological overview of the Pannonian halophytic vegetation in Slovakia. Kitaibelia 17(1): 40.

Mucina, L. (1993): Puccinellio-Salicornietea. In: Mucina, L., Grabherr, G. \& Ellmauer, T. (eds.): Die Pflanzengesellschaften Österreichs. Teil 1, Anthropogene Vegetation. Fischer, Stuttgart, New York, pp. 522-549.

Niklfeld, H. 1971: Bericht über die Kartierung der Flora Mitteleuropas. Taxon 20: 545-571.

Niklfeld, H. \& Schratt-Ehrendorfer, L. 1999: Rote Liste gefährdeter Farn- und Blütenpflanzen (Pteridophyta und Spermatophyta) Österreichs. 2. Fassung. In: Niklfeld, H. (ed.): Rote Listen gefährdeter Pflanzen Österreichs, ed. 2, Grüne Reihe des Bundesministerium für Umwelt, Jugend und Familie, Wien, pp. 33-151.

Nováková, J. 1997: Retreat of halophytes in the Czech Republic: agricultural, mining, and urbanization effects [the case of dentated melilot Melilotus dentata (Fabaceae)]. Journal of Agriculture Environment and Ethics 10(1):69-78.

Penksza, K. \& Király, G. 2009: Artemisia L. In: Király, G. (ed.): Új magyar füvészkönyv. Magyarország hajtásos növényei. Határozókulcsok. Aggteleki Nemzeti Park Igazgatóság, Jósvafő, p. $429-430$.

Persson, K. 1974: Biosystematic Studies in the Artemisia maritima Complex in Europe. Volume 2. Opera Botanica, Lund, 35: 1-188.

Sádovský M., Eliáš, P. ml. \& Dítě, D. 2004: Historické a súčasné rozšírenie slaniskových spoločenstiev na juhozápadnom Slovensku. Bulletin Slovenskej Botanickej Spoločnosti 26, Supl. 10: 127-129.

Schmidt, D. 2007: A Győr környéki szikesek növényzete. Flora Pannonica 5: 95-104.

Svobodová, Z. \& Řehořek, V.1985: Súčasný stav flóry a vegetácie Štátnej prírodnej rezrvácie Kamenínske slanisko a problematika jeho ochrany. Spravodaj Oblastného podunajského múzea Komárno, Sci. Natur. 5: 67-74.

Svobodová, Z., Řehořek, V. 1988: Významné lokality slanomilnej vegetácie v okrese Nové Zámky. In: Tajcnárová, E. \& Muránsky, P. (eds.): Zborník odborných prác V. západoslovenského TOP-u, Zväzok IV Kamenín, p. 21-30.

Svobodová, Z. \& Řehořek, V. 1992: Príspevok k flóre slanísk Podunajskej nížiny. Spravodaj Oblastného podunajského múzea Komárno, Sci. Natur. 10: 49-69. 
Šmarda, J. 1952: Př́íspěvek k poznání fytocenos slaných půd na jz. Slovensku. Preslia 24: 95-104.

Tutin, T.G. \& Persson, K.M. 1976: Artemisia L. In: Tutin, T.G., Heywood, V.H., Burges, N.A., Moore, D.M., Valentine, D.H., Walters, M., \& Webb, D.A. (eds.): Flora Europaea Vol. 4. Cambridge University Press, Cambridge, pp. 178-186.

Valachovič, M. 1995: Zonácia halofytnej vegetácie na slanisku pri Tvrdošovciach (Západné Slovensko). Bulletin Slovenskej Botanickej Spoločnosti, 17: 27-39.

Vallès, J. \& McArthur, E. D. (2011): Artemisia Systematics and Phylogeny: Cytogenetic and Molecular Insights. In: McArthur, E. D. \& Fairbanks, D. J. (eds.): Shrubland ecosystem genetics and biodiversity. USDA Forest Service Proceedings RMRS-P-21. Department of Agriculture, Forest Service, Rocky Mountain Research Station, pp. 67-74.

Vicherek, J. 1964: K rozšíření halofytní květeny na jihovýchodním Slovensku (Košická kotlina, Potiská nížina). Biológia 19: 555-557.

Vicherek, J. 1973: Die Pflanzengsellschaften der Halophyten und Subhalophytenvegetation der Tschechoslowakei. Vegetace ČSSR, ser. A, Praha, 5: 1-90.

Vozárová, M. \& Sutorý, K. (2001): Index herbariorum Reipublicae bohemicae et Reipublicae slovacae. Zprávy České Bot. Společn., Praha, 36, Príloha 2001/1; Bull. Slov. Bot. Spoločn., Bratislava, Suppl. 7, 95 pp.

Zlínska, J. 2003: Flóra a vegetácia slaniska Dérhídja na Podunajskej rovine. Biosozologia 1: 9-28.

Zlínska, J. 2005: Flóra a vegetácia rekultivovaného slaniska Bokroš na západnom Slovensku. Biosozologia 3: 1-16.

\section{APPENDIX}

List of localities of Artemisia santonicum subsp. santonicum in Slovakia (localities were arranged in direction west - east).

\section{Distr. 6. Podunajská nížina Lowland:}

Bratislava, saline steppes near Svätý Jur (Weber 1933 PR). = inter villages of Vajnory and Sv. Jur (Wiesbauer 1867: 967; Neilreich 1866: 34; Weber 1928 PR; 1934 PRC, 1936 BRNM). = Jurský Šúr site (Holuby 1914 BRA; Mikeš 19381: 124; Zig- mundík 1914 BRA; Domin 1920 PRC; Černý 1924 BRA; Nábělek sine data SAV; Černý et Suza 1932 BRNU; Novacký 1934 BRA; Ptačovský 1936 BRA; 1937 NI, 1938 SLO; Ptačovský 1934, 1938, 1955 SAV; Valenta 1939 BRA; Krist 1940, Futák 1947 SLO; Šmarda 1951 BRNM; Hodoval 1980 BRA; Grulich \& Feráková 1999; Eliáš jun. et Dítě 2008 NI). = Šúr, near Vel'ký majer farmstead (Černý 1954 PR; 1935 PRC; Horák 1962 PR). = Š́r, Čierna Voda site (Holuby 1914 PRC; Holuby 1956; Weber 1930 PR, 1932 BRNM). = Š́r, inter Háj site and Vel'ký majer farmstead (Ptačovský 1923, 1942 PR). - Tôn,, SE from the village (Májovský 1951 SLO). - Okoličná na Ostrove (Krist 1938 BRNU and 1940; Valenta 1938 BRA; Šmarda 1951 BRNM; Klokner 1958 BRA, PMK; Grulich \& Feráková 1999). - Zlatná na Ostrove E (Weber 1930, 1933, 1970, 1971 PR, 1936 BRA; Krist 1936 BRNU and 1936, 1940; Krippelová et Špániková 1962 SAV). - Zlatná na Ostrove, Pavol farmstead (Valenta 1936 BRA; Klokner 1972 PMK; Grulich \& Feráková 1999). = Čalovec, south from the village (Májovský 1951 SLO). - Malé Kosihy, Vel'ký Lél island (Mihálik 1964 SAV). - Vel'ké Kosihy (Májovský 1963 SLO; Grulich \& Feráková 1999). = Vel'ké Kosihy, Mostové Nature Reserve (Eliáš jun. et Dítě 2012 NI). - Vel'ké Kosihy, near the train station (Májovský 1963 SLO). Okánikovo (Májovský 1966 SLO; Feráková 1973 SLO; Grulich \& Feráková 1999; Eliáš jun. 2010 NI). - Komárno, Nová Stráž site (Weber 1933 PR, 1935 BRA; Klika \& Vlach 1937; Skřivánek 1950 BRA; BRNM; Májovský et Michalko 1951 SLO; Šmarda 1952, Grulich \& Feráková 1999) = Komárno, west from the town (Krist 1936; Futák 1949 SAV, SLO). - Komárno, near the train station (Weber 1933, 1971 PR; Šmarda 1951 BRNM and 1952; Klokner 1955 SLO; Hynšt 1957 OLM; Krippelová et Špániková 1962 SAV). - Iža E (Klokner 1955 SLO; Grulich \& Feráková 1999). = Bokrošské slanisko Nature Reserve (Zlínska 2005; Eliáš jun. et Dítě 2008 NI). - Patince [Path] (Chrtek et Žertová 1954 NI, Osvačilová 1954 NI; Grulich \& Feráková 1999). - Búč (Grulich \& Feráková 1999). - Komjatice, Ružový dvor farmstead (Klika 1934 PR; Vlach 1935 BRNM; Grulich \& Feráková 1999; Eliáš jun. 2012 NI). Hájske [Köpösd] (Scheffer 1923 BP; Krist 1936 BRNU and 1936; Grulich \& Feráková 1999). Hájske, Mešterik farmstead (Weber 1935, 1970, 1971 PR). = Trnovec nad Váhom, Mešterik farmstead (Weber 1935 BRNM). - Močenok, Siky (Krist 1936, 1937 BRNU and 1940; Weber 1936, 
1970 PR; Šourek 1950 PR; Smejkal 1965 BRNU; Grulich, Kochjarová et al. 1988 SLO; Grulich \& Feráková 1999; Matušicová \& Černušáková 2005; Eliáš jun. et Dítě 2010 NI). - Močenok, 1.5 km southwest from the Siky farmstead (Eliáš jun. 2008 NI). = Šal'a, N (Klokner 1955 SLO). - Horný Jatov (Krist 1936 BRNU and 1936, Pokluda 1960 BRNM). = Dolný Jatov, Čierny V́ŕšok site (Weber 1933, 1935 PR; Dostál 1953, 1955 PR). - Dolný Jatov (Knapp 1865b: 38; Krist 1936; Eliáš jun. 2010 NI). - Tvrdošovce (Krist 1936 BRNU and 1936, 1940; Valenta 1936 BRA; Šmarda 1949 BRNM and 1952; Pospíšil 1952 BRNM; Pokluda 1960 BRNM; Weber 1934 BRA; 1970 PR; Husák 1981 BRA; Pluhař 1986 BRNU; Eliáš jun. 1999 NI; Grulich \& Feráková 1999). - Tvrdošovce, Bačala farmstead (Krist 1936). = Palárikovo, Bačala farmstead (Weber 1935 PR, BRA, 1970, 1971 PR). - Palárikovo, NW from railway stop (Krist 1936 BRNU; Futák 1949 SLO; Součková 1950 BRNM; Šourek 1954 PR; Dvořák 1952 BRNM; Pokluda 1961 BRNM; Kříž 1967 BRNM). = Palárikovo, near train lines (Weber 1935 PR; Krist 1936, Jirásek 1937; Futák 1949 SAV). - Palárikovo, south from the train stop (Krist 1940). - Palárikovo, Malé Čiky farmstead (Weber 1936 BRNM, 1936 BRA, PR, 1935, 1937, 1970 PR). - Palárikovo, Berchtold farmstead (Weber 1970 PR). Šurany, Vel'ké Čiky farmstead (Weber 1936, 1970 PR, 1960 BRNM; Kř́ž et Weber 1947 BRNM; Smejkal 1965 BRNU; Unar 1965 BRNU; Jasenák 1974 LTM). = Šurany, Čiky site (Deyl 1954 PR). - Šurany, Akomáň farmstead (Weber 1935, 1970 PR; Krist 1936, Kř́žz et Weber 1947 BRNM; Grulich \& Feráková 1999; Eliáš jun. et Sádovský 2004 NI). - Šurany, Čiastka gamekeeper's house (Weber 1935, 1970 PR; Krist 1937 BRNU, 1940) Bíňa (A. Hayek 1914a: 158; Osvačilová 1955 NI). - Kamenín, Alsó rétek site (Feichtinger 1861, 1862 BP, 1899: 30; Boros 1917 BP; Skřivánek 1948 BRA; BRNM; Šmarda 1951 BRNM and 1952; Švec 1953 LTM; Jasenák 1976 LTM). = Kamenín, Kamenínske slanisko Nature Reserve (Krist et Skřivánek 1935 BP, BRNU, BRNM, CL, MZ, NI, PR, PRC, SLO, ZV; Krist 1935, 1936, 1940; Domin 1936 ined.; Nábělek 1936 BRA, SAV, 1953 SAV; Weber 1936 BRNM; Klika \& Vlach 1937; V. Deyl 1938 CL, PR, 1951 PR; Dvořák 1947 BRNM, BRNU; Futák 1947 SLO; Novotný 1947 BRNM; Šmarda 1947, 1949 BRNM; Skřivánek 1949 BRA; Novák 1950 BRNM; Šourek 1950 PR; Jedlička 1950 BRNU; Hrabětová 1950 BRNU; Černoch 1951 BRNM; Komárek 1951 MZ; Ondráková
1952 PR; Žertová 1953 PR; Šourek 1950, 1954 PR; Grebenščikov 1955 SAV; Osvačilová 1956 NI; Májovský 1957 SLO; Futák 1957 SAV; Futák et Hlavaček 1958 SAV; Chrtková 1968 PR; Č. Deyl 1957 OLM; Gruber 1958 BRA; Dostál 1968 PR; Čvančara 1971 BRNU; Jasenák 1974 LTM; Svobodová 1968, 1982 NI; Grulich \& Feráková 1999; Eliáš jun. et Dítě 2012 NI). - between settlements of Kamenín and Kamenný Most (Boros 1917 BP; F. Weber 1935 CL, PR; Domin et Jirásek 1936 PRC; Jávorka 1939 BP; Krist 1941; Deyl et Soják 1964 PR; Smejkal 1959, 1965 BRNU) = Kamenný Most, Irtoványi rétek site (Valenta 1938 BRA; Skřivánek 1948 BRNM). = Kamenný Most (Feichtinger 1853, 1861, 1862 BP, 1862 BRNU, 1899: 30; Krist 1935 BRNU and 1935, 1936; Weber 1928, 1936 PR; 1934 PRC, 1935 SLO; Pospíšil 1952 BRNM; Šourek 1954; Manica 1962 ZV; Hodoval 1976 BRA; Grulich \& Feráková 1999). = Kamenný Most, Čistiny site (David 1988 LTM; Eliáš jun. et Dítě 2012 NI). - Obid, near Boží kopec hill [Ebed, Isten-hegy] (Feichtinger 1899: 30).

\section{Distr. 8. Východoslovenská nížina Lowland:} Zemplínske Kopčany, Kopčianske slanisko Nature Reserve, 10 individuals (Bogoly 1994; Grulich \& Feráková 1999; Eliáš jun., Dítě et Šuvada 2009 NI). = Malčice (Kühn 1962 BRNU; Vicherek 1963 BRNU; Májovský 1964 SLO; sine coll. 1969 BRA). - Vel'ké Raškovce, $1.5 \mathrm{~km}$ NW from the village (Vicherek 1963 BRNU).

Common data (not mapped): District of Nitra (Borbás 1905d: 38). - Inundation of the Tisa river (Reuss 1853: 228).

Doubtful data (not mapped): Šal'a, saline site (Urvichiarová 1963 BRA; Hajdúk 1971 BRA). Those data are probably related to Siky farmstead or Mešterik farmstead near Močenok. - Čenkov (Bertová 1968 BRA). The location represents sandy habitats and occurrence of $A$. santonicum is not likely.

Erorneous data (not mapped): Záhorská Ves [Uhorská Ves], Moravské Pole site [Marschfeld] (H. Braun 1889: 186; Degen, Gáyer \& Scheffer 1923: 112; Grulich \& Feráková 1999).

Received 20. 12. 2012

Revision received 2. 4. 2013 Accepted 5. 4. 2013 